\title{
Reaksi Pasar atas Penyebaran Coronavirus Disease 2019 (COVID-19)
}

\author{
Alfian Nurwanto Putra1 \\ Fakultas Ekonomi dan Bisnis \\ Universitas Udayana, Indonesia
}

\author{
I Nyoman Wijana Asmara Putra ${ }^{2}$ \\ Fakultas Ekonomi dan Bisnis \\ Universitas Udayana, Indonesia
}

Surel : alfian.secret@gmail.com

\section{ABSTRAK}

COVID-19 menjadi sentimen negatif bagi pasar saham di seluruh dunia. Pada Senin 2 Maret 2020, Presiden RI Joko Widodo mengumumkan temuan kasus infeksi COVID-19 pertama di Indonesia. Penelitian ini bertujuan untuk menguji apakah terdapat reaksi pasar atas penyebaran COVID-19. Reaksi pasar dalam penelitian ini diukur dengan abnormal return, yaitu selisih antara return ekspektasian dan return realisasi. Abnormal return dalam penelitian ini diestimasi dengan menggunakan marketadjusted model. Penelitian ini dilakukan pada emiten yang termasuk dalam anggota indeks LQ 45. Sampel pada penelitian ditentukan menggunakan teknik purposive sampling. Penelitian ini dilakukan dengan menggunakan 2 Maret 2020 dan 9 Maret 2020 sebagai tanggal peristiwa. Jumlah perusahaan yang digunakan dalam penelitian ini berjumlah 45 perusahaan. Hasil dari penelitian ini menunjukkan bahwa pada 2 Maret 2020 tidak terdapat reaksi pasar atas penyebaran COVID-19, sedangkan pada 9 Maret 2020 terdapat reaksi pasar atas penyebaran COVID-19.

Kata Kunci: Studi Peristiwa; Abnormal Return; COVID-19.

\section{Market Reaction to the Spread of Coronavirus Disease 2019 (COVID-19)}

\begin{abstract}
COVID-19 has become a negative sentiment for stock markets around the world. On Monday, March 2, 2020, Indonesian President Joko Widodo announced the findings of the first COVID-19 infection case in Indonesia. This study aims to test whether there is a market reaction to the spread of COVID-19. Market reaction in this study is measured by abnormal returns, which is the difference between expected returns and realized returns. Abnormal returns in this study were estimated using a market-adjusted model. This study was conducted on issuers included in the LQ 45 index. The sample in this study was determined using purposive sampling technique. This research was conducted using March 2, 2020 and March 9, 2020 as the date of the event. The number of companies used in this study amounted to 45 companies. The results of this study indicate that on March 22020 there was no market reaction to the spread of COVID-19, while on March 92020 there was a market reaction to the spread of COVID-19.
\end{abstract}

Keywords: Event Studies; Abnormal Return; COVID-19.

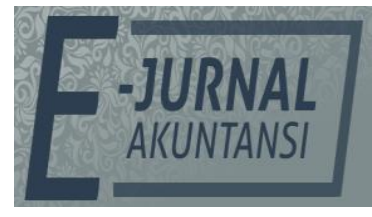

e-ISSN 2302-8556

Vol. 31 No. 3

Denpasar, Maret 2021

Hal. 577-590

DOI:

10.24843/EJA.2021.v31.i03.p05

PENGUTIPAN:

Putra, A.N., \& Putra, I

N.W.A.P. (2021). Reaksi

Pasar atas Penyebaran

Coronavirus Disease 2019

(COVID-19). E-Jurnal

Akuntansi, 31(3), 577-590

RIWAYAT ARTIKEL:

Artikel Masuk:

22 Juli 2020

Artikel Diterima:

19 Februari 2021

Artikel dapat diakses : https://ojs.unud.ac.id/index.php/Akuntansi/index 


\section{PENDAHULUAN}

Pasar modal merupakan instrumen ekonomi yang penting dan merupakan indikator kemajuan perekonomian suatu negara. Pasar modal memiliki peran penting bagi perekonomian suatu negara karena dua fungsi pasar modal, yaitu pertama, sebagai sarana bagi pendanaan usaha atau sebagai sarana untuk perusahaan sebagai tambahan dana dari pemodal atau investor (Husnan, 2015). Kedua, pasar modal menjadi sarana bagi msayarakat untuk berinvestasi pada instrumen keuangan seperti obligasi, saham, reksadana, dan lain sebagainya.

Investor dituntut untuk mengetahui peristiwa-peristiwa penting baik ekonomi maupun non ekonomi yang meliputi peristiwa politik, sosial, budaya, dan yang dapat mengganggu stabilitas nasional seperti penyebaran virus COVID-19 yang sedang terjadi di negara- negara di seluruh dunia. Indonesia sebagai salah satu negara yang terdampak COVID-19 juga mengalami penurunan di berbagai sektor terutama pada finansial dan investasi khususnya di sektor penerbangan, hotel, restoran, pariwisata, pengiriman, transportasi. Hal tersebut merupakan akibat dari himbauan pemerintah untuk melakukan physical distancing, bekerja, belajar, dan beribadah di rumah.

Pada Desember 2019, kasus pneumonia misterius pertama kali dilaporkan di Kota Wuhan, Provinsi Hubei. Sumber penularan kasus ini masih belum diketahui pasti, tetapi kasus pertama dikaitkan dengan pasar ikan di Wuhan (Rothan \& Byrareddy, 2020). Sejak 31 Desember 2019 hingga 3 Januari 2020 kasus ini meningkat pesat, ditandai dengan dilaporkannya sebanyak 44 kasus. Tidak sampai satu bulan, penyakit ini telah menyebar di berbagai provinsi lain di China, Thailand, Jepang, dan Korea Selatan (Huang et al., 2020). Organisasi Kesehatan Dunia (WHO) pada 12 Februari 2020 secara resmi menamai virus tersebut dengan nama COVID-19. COVID-19 merupakan singkatan dari coronavirus disease that was discovered in 2019 yang artinya penyakit virus corona yang ditemukan pada 2019 (www.wartaekonomi.co.id, 2020).

Virus ini dapat ditularkan dari manusia ke manusia dan telah menyebar secara luas di China dan lebih dari 190 negara dan teritori lainnya. Pada 12 Maret 2020, WHO mengumumkan COVID-19 sebagai pandemi. Hingga tanggal 29 Maret 2020, terdapat 634.835 kasus dan 33.106 jumlah kematian di seluruh dunia. Sementara di Indonesia sudah ditetapkan 1.528 kasus dengan positif COVID-19 dan 136 kasus kematian (Susilo et al., 2020).

Sejak kasus pertama di Wuhan, terjadi peningkatan kasus COVID-19 di China setiap hari dan memuncak diantara akhir Januari hingga awal Februari 2020. Awalnya kebanyakan laporan datang dari Hubei dan provinsi di sekitar, kemudian bertambah hingga ke provinsi-provinsi lain dan seluruh China (Zunyou \& McGoogan, 2020). Tanggal 30 Januari 2020, telah terdapat 7.736 kasus terkonfirmasi COVID-19 di China, dan 86 kasus lain dilaporkan dari berbagai negara seperti Taiwan, Thailand, Vietnam, Malaysia, Nepal, Sri Lanka, Kamboja, Jepang, Singapura, Arab Saudi, Korea Selatan, Filipina, India, Australia, Kanada, Finlandia, Prancis, dan Jerman (Susilo et al., 2020).

Hingga 28 Maret 2020, jumlah kasus infeksi COVID-19 terkonfirmasi mencapai 571.678 kasus. Awalnya kasus terbanyak terdapat di Cina, namun saat ini kasus terbanyak terdapat di Italia dengan 86.498 kasus, diikut oleh Amerika dengan 85.228 kasus dan China 82.230 kasus. Virus ini telah menyebar hingga ke 
199 negara. Kematian akibat virus ini telah mencapai 26.494 kasus. Tingkat kematian akibat penyakit ini mencapai $4-5 \%$ dengan kematian terbanyak terjadi pada kelompok usia di atas 65 tahun. Indonesia melaporkan kasus pertama pada 2 Maret 2020, yang diduga tertular dari orang asing yang berkunjung ke Indonesia. Kasus di Indonesia pun terus bertambah, hingga tanggal 29 Maret 2020 telah terdapat 1.115 kasus dengan kematian mencapai 102 jiwa. Tingkat kematian Indonesia 9\%, termasuk angka kematian tertinggi (Handayani et al., 2020).

Berdasarkan data yang ada, umur pasien yang terinfeksi COVID-19 mulai dari usia 30 hari hingga 89 tahun. Menurut laporan 138 kasus di Kota Wuhan, didapatkan rentang usia 37-78 tahun dengan rerata 56 tahun (42-68 tahun) tetapi pasien rawat ICU lebih tua (median 66 tahun (57-78 tahun) dibandingkan rawat non-ICU (37-62 tahun) dan 54,3\% laki-laki. Laporan 13 pasien terkonfirmasi COVID-19 di luar Kota Wuhan menunjukkan umur lebih muda dengan median 34 tahun (34-48 tahun) dan 77\% laki laki (Lu et al., 2020).

COVID-19 menjadi sentimen negatif bagi pasar saham di seluruh dunia. Pada penutupan perdagangan 27 Januari 2020, indeks Dow Jones turun 1,57\%, indeks S\&P 500 turun 1,57\%, dan indeks Nasdaq Composite turun 1,89\% (CNBC Indonesia, 2020). Bursa Asia pada Senin 3 Februari 2020 pukul 8.28 WIB, indeks Nikkei 225 turun 1,43\% ke 22.871. Indeks Hang Seng terkoreksi 0,47\% ke 26.189. Indeks Taiex Taiwan turun 2,47\% ke 11.212. Kospi Korea turun 1,57\% ke 2.085. Sedangkan, Straits Times Singapore turun 0,75\% ke 3.130. Indeks Shanghai mengalami penurunan 8,6\% pada pembukaan perdagangan 3 Februari 2020 setelah libur panjang Hari Raya Imlek 24 Januari 2020 (www.kontan.co.id, 2020).

IHSG pada perdagangan 30 Desember 2019 berada di level 6.299,5. Level tertinggi indeks pada hari terakhir perdagangan saham di BEI itu mencapai 6.336,9, sedangkan terendahnya mencapai 6.289,5. Nilai transaksi harian mencapai Rp 11,4 triliun. IHSG pada penutupan perdagangan Senin 3 Februari 2020 berada di level 5.884,17. Level tertinggi indeks mencapai 5.942,7 sedangkan terendahnya mencapai 5.877,2. Nilai transaksi harian mencapai Rp 6,6 triliun (Investor Daily, 2020).

Setelah beberapa hari kemudian, pada Senin 2 Maret 2020, Presiden RI Joko Widodo didampingi Menteri Kesehatan Terawan Agus Putranto, Sekretaris Kabinet Pramono Anung, dan Menteri Sekretaris Negara Pratikno mengumumkan temuan kasus infeksi COVID-19 pertama di Indonesia (ANTARA.news, 2020). Informasi tersebut menyebabkan Indeks Harga Saham Gabungan (IHSG) turun 1,02\% ke level 5.397 pada penutupan perdagangan sesi pertama Senin 2 Maret 2020 (www.katadata.co.id, 2020). Presiden Joko Widodo (Jokowi) menetapkan bencana non-alam COVID-19 sebagai bencana nasional. Pemerintah menyatakan bahwa seluruh integrasi data dari tingkat desa/kelurahan hingga pusat berada dalam satu sistem (Detiknews, 2020). Berdasarkan Keputusan Presiden (Keppres) Nomor 12 Tahun 2020 tanggal 13 April 2020 tentang Penetapan Bencana Non-alam Penyebaran COVID-19, maka COVID-19 ditetapkan sebagai bencana nasional (Keppres No 12, 2020).

Perubahan keadaan pasar dapat dipengaruhi oleh peristiwa internal atau peristiwa yang berasal dari dalam perusahaan. Peristiwa pengumuman informasi laba perusahaan menyebabkan pasar bereaksi (Maharani, 2014). 
Peristiwa pemecahan saham atau stock split dari anggota indeks LQ45 juga dapat membuat pasar bereaksi (Meylita P \& Yasa, 2015). Peristiwa dividend omission atau kebijakan penghapusan dividen untuk pertama kalinya setelah dua kali berturut-turut membagikan dividen mendapat reaksi negatif dari pasar (Pertiwi \& Wirama, 2019). Penelitian Firstiany \& Wirama (2019) menunjukkan bahwa menunjukkan bahwa pasar tidak bereaksi atas pengumuman right issue.

Peristiwa eksternal atau peristiwa yang berasal dari luar perusahaan juga dapat mempengaruhi keadaan pasar. Suatu peristiwa yang terjadi di luar negeri dapat mempengaruhi keadaan bursa di indonesia. Seperti contoh, berdasarkan penelitian Costa \& Sukartha (2020) menunjukan bahwa terdapat terdapat reaksi pasar di pasar saham AS, China dan Indonesia atas pengumuman hasil perundingan perang dagang AS-China fase 1. Berdasarkan penelitian Indrayuda \& Sukartha (2019) menemukan bahwa pasar bereaksi atas peristiwa kenaikan The Federal Funds Rate tanggal 26 September 2018. Kenaikan suku bunga Bank Indonesia juga dapat mempengaruhi pasar. Penelitian Mahendra \& Rasmini (2019) menunjukkan bahwa kenaikan BI 7-Day Reverse Repo Rate pada tanggal 15 Agustus 2018 direspon oleh pasar.

Peristiwa yang tidak berhubungan langsung dengan pasar modal juga dapat berpengaruh pada keadaan pasar. Seperti penelitian Putra \& Putri (2018) yang menunjukkan bahwa pengumuman kemenangan Donald Trump menjadi presiden Amerika Serikat yang membuat pasar bereaksi. Peristiwa politik yang terjadi di dalam negeri juga mempengaruhi keadaan pasar. Berdasarkan penelitian Melati et al., (2015) menunjukkan bahwa peristiwa pemilihan Presiden 9 Juli 2014 mempengaruhi pasar. Peristiwa pelantikan Presiden dan Wakil Presiden terpilih hasil Pemilihan Umum tahun 2014 berdasarkan penelitian Sopyana \& Yasa (2016) juga membuat pasar bereaksi.

Menurut Watts \& Zimmerman (1990), menyatakan bahwa kandungan informasi digunakan untuk menguji isu-isu apakah suatu event mempengaruhi harga saham pada saat event tersebut. Kandungan informasi merupakan release berita baru atau pengumuman yang menyebabkan perubahan dalam distribusi return efek (Foster, 1986).

Hanafi (2004) mendefinisikan bahwa teori efisiensi pasar adalah teori yang membahas mengenai harga atau nilai sekuritas yang mencerminkan secara penuh semua informasi yang tersedia pada informasi tersebut. Respon pasar terhadap informasi merupakan hal yang perlu diperhatikan oleh perusahaan, karena harga dari saham perusahaan akan bergantung pada investor.

Menurut teori efisiensi pasar bentuk setengah kuat (Semistrong Form) yang dikemukakan oleh Fama (1970), suatu informasi yang dipublikasikan akan mempengaruhi harga saham semua perusahaan yang terdatar di bursa efek. Berdasarkan kajian empiris penelitian dari Putra \& Putri (2018) yang menyatakan bahwa terdapat kandungan informasi pada persitiwa pengumuman kemenangan Donald Trump menjadi presiden Amerika Serikat. Berdasarkan penelitian Hatmanti \& Sudibyo (2017), pasar juga bereaksi terhadap pelantikan Kabinet Kerja hasil reshuffle jilid II. Sementara itu, berdasarkan penelitian Wahyudhi \& Suaryana (2019) menunjukkan bahwa terdapat reaksi negatif pasar 
modal atas pengumuman kesepakatan investasi bidang infrastruktur dalam pertemuan tahunan IMF-World Bank 2018.

Berdasarkan kajian empiris diatas, dapat disimpulkan bahwa teori kandungan informasi menurut Watts \& Zimmerman (1990) yang menyatakan bahwa kandungan informasi digunakan untuk menguji isu-isu apakah suatu event mempengaruhi harga saham pada saat event tersebut telah terbukti. Penetapan tanggal 2 Maret 2020 berdasarkan pada pengumuman Presiden RI yang telah melaporkan kasus pertama pada 2 Maret 2020 (Handayani et al., 2020). Berdasarkan uraian diatas, maka penulis merumuskan hipotesis sebagai berikut: $\mathrm{H}_{1}$ : Terdapat reaksi pasar pada tanggal 2 Maret 2020.

Penetapan tanggal 9 Maret 2020 berdasarkan pada peningkatan jumlah kasus positif dan meluasnya penyebaran COVID-19 yang menjadi sentimen negatif IHSG pada 9 Maret 2020 (pasardana.id, 2020). Penetapan 2 tanggal sebagai t0 dalam penelitian event study telah dilakukan oleh beberapa penelitian terdahulu. Sanjiwani \& Jati, (2017) dalam penelitiannya menggunakan 2 tanggal sebagai t0. Penetapan t0 yang pertama berdasarkan tanggal pengumuman kebijakan tax amnesty yaitu 28 Juni 2016 pada saat pengesahan UU tax amnesty oleh DPR (www.bbc.com, 2016). Penetapan t0 yang kedua berdasarkan tanggal berakhirnya periode I tax amnesty yaitu tanggal 30 September 2016. Pratama et al., (2020) dalam penelitiannya juga menggunakan 2 tanggal sebagai t0. Penetapan t0 yang pertama adalah pada 21 Mei 2019. Penetapan tersebut berdasarkan pengumuman resmi KPU tentang hasil Pilpres 2019. Penetapan t0 yang kedua adalah pada 27 Juni 2019. Penetapan tersebut berdasarkan putusan Mahkamah Konstitusi tentang sengketa Pilpres 2019.

Berdasarkan uraian diatas, penelitian event study memungkinkan untuk menggunakan 2 tanggal sebagai t0. Maka, penulis merumuskan hipotesis sebagai berikut:

$\mathrm{H}_{2}$ : Terdapat reaksi pasar pada tanggal 9 Maret 2020.

\section{METODE PENELITIAN}

Penelitian ini termasuk dalam kategori event study atau study peristiwa. Studi peristiwa (event study) merupakan studi yang mempelajari reaksi pasar terhadap suatu peristiwa (event) yang informasinya dipublikasikan sebagai suatu pengumuman. Event study dapat digunakan untuk menguji kandungan informasi (information content) dari suatu pengumuman dan dapat juga digunakan untuk menguji efisiensi pasar bentuk setengah kuat (Hartono, 2017). Penelitian ini dilakukan di Bursa Efek Indonesia. Data perusahaan-perusahaan yang digunakan dalam penelitian ini diperoleh dari www.idx.co.id, www.sahamok.com, id.investing.com, dan finance.yahoo.com. Alasan pemilihan lokasi di Bursa Efek Indonesia karena tersedianya data yang lengkap. Obyek penelitian yang diteliti adalah pergerakan harga saham di pasar modal pada perusahaan yang terdaftar dalam indeks LQ45. Peneliti menetapkan event date (t0) pada tanggal 2 Maret 2020 dan 9 Maret 2020. Penetapan tanggal 2 Maret 2020 sebagai event date ( $\mathrm{t} 0)$ pertama adalah karena Presiden Joko Widodo mengumumkan kasus pertama COVID-19 di Ineonesia. Peneliti menetapkan 7 hari sebagai jendela peristiwa (event window). 
Variabel dalam penelitian ini adalah abnormal return, dimana abnormal return merupakan selisih antara return yang terjadi sesungguhnya (actual return) dengan return ekspektasian (expected return) yang dapat terjadi terhadap suatu peristiwa yang tak terduga. Actual Return merupakan return yang terjadi sesungguhnya dan menunjukkaan besarnya keuntungan investor yang menanamkan modalnya dalam bentuk saham biasa. Actual Return dinyatakan dalam persentase dan dapat dihitung dengan rumus sebagai berikut.

$R_{i, t}=\frac{P_{i, t}-P_{i, t-1}}{P_{i, t-1}}$

Sumber: Hartono (2017)

Notasi:

$R_{i, t} \quad=$ return sesungguhnya yang terjadi untuk saham ke-i pada periode ke-t

$P_{i, t} \quad=$ harga sekarang relatif

$P_{i, t-1}=$ harga sebelumnya

Expected Return atau return ekspektasian merupakan return yang digunakan untuk pengambilan keputusan investasi. Return ini penting jika dibandingkan dengan return historis karena return ekspektasian merupakan return yang diharapkan dari investor. Peneliti menghitung expected return dengan menggunakan market-adjusted model. Berikut adalah rumus menghitung expected return dengan menggunakan market-adjusted model.

$R_{m, t}=\frac{I H S G_{i, t}-I H S G_{i, t-1}}{I H S G_{i, t-1}}$

Sumber: Hartono (2017)

Notasi:

$R_{m, t} \quad=$ return pasar pada waktu $\mathrm{t}$

$I_{I H S G_{i, t}} \quad=$ nilai IHSG pada saat $\mathrm{t}$

$I H S G_{i, t-1} \quad=$ nilai IHSG pada saat $\mathrm{t}-1$

Abnormal Return adalah selisih antara return yang terjadi sesungguhnya (actual return) dengan return ekspektasian (expected return). Abnormal Return dinyatakan dalam persentase dan dapat dihitung dengan rumus sebagai berikut.

$A R_{i, t}=R_{i, t}-R_{m, t}$

Sumber: Hartono (2017)

Notasi:

$A R_{i, t} \quad=$ abnormal return saham i pada hari ke $\mathrm{t}$

$R_{i, t} \quad=$ actual return saham i pada hari ke $\mathrm{t}$

$E R_{i, t} \quad=$ return ekspektasi saham ke-i untuk periode peristiwa ke-t

Cummulative Abnormal Return merupakan penjumlahan return tak normal (abnormal return) hari sebelumnya di dalam periode peristiwa untuk masingmasing saham, dapat dihitung dengan rumus sebagai berikut (Hartono, 2017).

$C A R_{i, t}=\sum_{t=t 3}^{t=0} A R_{i, t}$

Sumber: Hartono (2017)

Notasi:

$C A R_{i, t}=$ Cummulative Abnormal Return perusahaan ke-i pada periode ke-t, yang diakumulasikan dari $A R_{i, t}$ saham ke-i pada periode peristiwa (t-3) sampai dengan $(\mathrm{t}+3)$

Penelitian ini menggunakan jenis data kuantitatif yaitu data yang berupa angka-angka dan menggunakan sumber data sekunder yang diperoleh dari web id.investing.com dan yahoo finance. Alasan menggunakan data sekunder adalah 
dikarenakan data sekunder lebih mudah diperoleh, biayanya lebih murah, serta keabsahannya dapat dipercaya. Populasi adalah wilayah generalisasi yang terdiri atas obyek atau subyek yang mempunyai kualitas dan karakteristik tertentu yang ditetapkan oleh peneliti untuk dipelajari dan kemudian ditarik kesimpulannya (Sugiyono, 2017). Populasi dalam penelitian ini adalah sahamsaham perusahaan yang terdaftar dalam indeks LQ45. Sampel dalam penelitian ini ditentukan menggunakan metode purposive sampling yaitu dengan cara menetapkan ciri-ciri khusus yang sesuai dengan tujuan penelitian. Metode pengumpulan data yang digunakan dalam penelitian ini adalah metode observasi non partisipan, yaitu metode pengumpulan data dengan observasi atau pengamatan dimana peneliti tidak terlibat secara langsung dan hanya sebagai pengamat independen (Sugiyono, 2017).

One sample t-test merupakan salah satu uji parametrik. Uji one sample t-test merupakan uji yang digunakan untuk membandingkan satu variable bebas. Syaratnya adalah data harus bersifat kuantitatif dan memiliki distribusi normal. Tujuan pengujian dengan one sample t-test yaitu untuk memperlihatkan apakah terdapat abnormal return yang signifikan di sekitar jendela peritiwa (event window). Signifikansi yang dimaksud yaitu bahwa abnormal return tersebut secara statistk signifikan tidak sama dengan nol (positif untuk kabar baik dan negatif untuk kabar buruk) (Tandelilin, 2010). Jika data berdistribusi normal dengan menentukan tingkat signifikansi $\alpha=5 \%, d f=n-1$.

\section{HASIL DAN PEMBAHASAN}

Statistik deskriptif disajikan untuk memberikan informasi mengenai karakteristik variabel-variabel penelitian, yaitu jumlah sampel, nilai rata-rata (mean), dan standar deviasi (deviation standard) dan rata-rata standar error (standard error mean). Hasil statistik deskriptif penelitian ini disajikan berdasarkan acuan t0. Hasil statistik deskriptif berdasarkan acuan t0 2 Maret dapat dilihat pada Tabel 1, berikut

Tabel 1. Hasil Uji Statistik Deskriptif t0 2 Maret

\begin{tabular}{llrr}
\hline & Descriptives & & \\
\hline CAR & & Statistic & Std. Error \\
Mean & &, 003982 &, 0075108 \\
for Mean & Lower Bound &,- 011155 & \\
$5 \%$ Trimmed Mean & Upper Bound &, 019119 & \\
Median & &, 002756 & \\
Variance &, 004400 & \\
Std. Deviation &, 003 & \\
Minimum &, 0503840 & \\
Maximum &,- 1188 & \\
Range &, 1423 & \\
Interquartile Range &, 2611 & \\
Skewness &, 0694 & \\
Kurtosis &, 268 & \\
\hline
\end{tabular}

Sumber: Data Penelitian, 2020 
Berdasarkan statistik deskriptif, rata-rata CAR adalah sebesar 0,003982. Standar deviasi dari CAR adalah sebesar 0,0503840. Standar error rata-rata adalah sebesar 0,0075108. Nilai minimum dalam data tersebut adalah $-0,1188$ yang merupakan saham AKRA. Nilai maximum dalam data tersebut adalah 0,1423 yang merupakan saham TKIM.

Hasil statistik deskriptif berdasarkan acuan t0 9 Maret dapat dilihat pada Tabel 2, berikut

Tabel 2. Hasil Uji Statistik Deskriptif t0 9 Maret

\begin{tabular}{|c|c|c|c|c|}
\hline \multicolumn{5}{|c|}{ Descriptives } \\
\hline & & & Statistic & Std. Error \\
\hline \multirow[t]{13}{*}{ CAR } & Mean & &,- 092776 & ,0147342 \\
\hline & $95 \%$ Confidence Interval & Lower Bound &,- 122470 & \\
\hline & for Mean & Upper Bound &,- 063081 & \\
\hline & $5 \%$ Trimmed Mean & &,- 092312 & \\
\hline & Median & &,- 100100 & \\
\hline & Variance & & ,010 & \\
\hline & Std. Deviation & & ,0988403 & \\
\hline & Minimum & &,- 3110 & \\
\hline & Maximum & & ,1141 & \\
\hline & Range & & 4251 & \\
\hline & Interquartile Range & & 1577 & \\
\hline & Skewness & &,- 086 & ,354 \\
\hline & Kurtosis & &,- 383 &, 695 \\
\hline
\end{tabular}

Sumber: Data Penelitian, 2020

Berdasarkan statistik deskriptif, rata-rata CAR adalah sebesar 0,092776. Standar deviasi dari CAR adalah sebesar 0,0988403. Standar error rata-rata adalah sebesar 0,0147342. Nilai minimum dalam data tersebut adalah $-0,3110$ yang merupakan saham WIKA. Nilai maximum dalam data tersebut adalah 0,1141 yang merupakan saham UNVR.

Uji normalitas yang digunakan dalam penelitian ini adalah uji KolmogorovSmirnov. Hasil uji Kolmogorov-Smirnov disajikan berdasarkan acuan t0. Hasil uji Kolmogorov-Smirnov disajikan berdasarkan acuan t0 2 Maret dapat dilihat pada Tabel 3, berikut.

Tabel 3. Hasil Uji Normalitas t0 2 Maret

\begin{tabular}{rrrrrrrr}
\hline \multicolumn{8}{c}{ Tests of Normality } \\
& \multicolumn{8}{c}{ Kolmogorov-Smirnova } & \multicolumn{3}{c}{ Shapiro-Wilk } \\
\cline { 2 - 8 } & Statistic & $d f$ & Sig. & Statistic & \multicolumn{1}{c}{$d f$} & Sig. \\
\hline CAR &, 059 & 45 &, $200^{*}$ &, 985 & 45 &, 804 \\
\hline
\end{tabular}

*. This is a lower bound of the true significance.

a. Lilliefors Significance Correction

Sumber: Data Penelitian, 2020

Berdasarkan hasil uji statistik Kolmogorov-Smirnov (K-S) diatas, dapat dilihat bahwa nilai signifikansi 0,2 >0,05. Nilai tersebut menandakan bahwa data CAR berdistribusi mormal.

Hasil uji Kolmogorov-Smirnov disajikan berdasarkan acuan t0 9 Maret dapat dilihat pada Tabel 4, berikut. 
Tabel 4. Hasil Uji Normalitas t0 9 Maret

\begin{tabular}{cccccccc}
\hline \multicolumn{8}{c}{ Tests of Normality } \\
\hline & Statistic & $d f$ & Sig. & Statistic & $d f$ & Shapiro-Wilk \\
\cline { 2 - 8 } &, 089 & 45 &, $200^{*}$ &, 979 & & 45 & Sig. \\
\hline
\end{tabular}

*. This is a lower bound of the true significance.

a. Lilliefors Significance Correction

Sumber: Data Penelitian, 2020

Berdasarkan hasil uji statistik Kolmogorov-Smirnov (K-S) diatas, dapat dilihat bahwa nilai signifikansi 0,2 >0,05. Nilai tersebut menandakan bahwa data CAR berdistribusi mormal.

One sample t-test merupakan salah satu uji parametrik. Uji one sample t-test merupakan uji yang digunakan untuk membandingkan satu variable bebas. Syaratnya adalah data harus bersifat kuantitatif dan memiliki distribusi normal. Apabila data tidak memenuhi syarat distribusi normal, maka analisa menggunakan statistik uji non-parametrik. Hasil uji one sample t-test penelitian ini disajikan berdasarkan acuan t0. Hasil uji one sample t-test berdasarkan acuan t0 2 Maret dapat dilihat pada Tabel 5, berikut.

Tabel 5. Hasil Uji One Sample T-Test t0 2 Maret

\begin{tabular}{|c|c|c|c|c|c|c|}
\hline \multicolumn{7}{|c|}{ One-Sample Test } \\
\hline & \multicolumn{6}{|c|}{ Test Value $=0$} \\
\hline & \multirow[t]{2}{*}{$t$} & \multirow[t]{2}{*}{$d f$} & \multirow[t]{2}{*}{$\begin{array}{l}\text { Sig. (2- } \\
\text { tailed) }\end{array}$} & \multirow[t]{2}{*}{$\begin{array}{c}\text { Mean } \\
\text { Difference }\end{array}$} & $\begin{array}{r}95 \% \text { Confidenc } \\
\text { Diffe }\end{array}$ & al of the \\
\hline & & & & & Lower & Upper \\
\hline CAR &, 530 & 44 & ,599 & ,0039822 &,- 011155 & 019119 \\
\hline
\end{tabular}

Sumber: Data Penelitian, 2020

Berdasarkan hasil uji one sample t-test diatas dapat dilihat bahwa nilai signifikansi sebesar 0,599 >0,05. Nilai signifikansi > 0,05 menunjukkan bahwa tidak terdapat reaksi pasar pada 2 Maret.

Hasil uji one sample t-test berdasarkan acuan t0 9 Maret dapat dilihat pada Tabel 6, berikut.

Tabel 6. Hasil Uji One Sample T-Test t0 9 Maret

\begin{tabular}{|c|c|c|c|c|c|}
\hline \multicolumn{6}{|c|}{ One-Sample Test } \\
\hline & \multicolumn{5}{|c|}{ Test Value $=0$} \\
\hline & \multirow[t]{2}{*}{$t$} & \multirow[t]{2}{*}{$d f$} & \multirow[t]{2}{*}{$\begin{array}{l}\text { Sig. }(2- \\
\text { tailed })\end{array}$} & \multirow[t]{2}{*}{$\begin{array}{c}\text { Mean } \\
\text { Difference }\end{array}$} & $\begin{array}{c}\text { 95\% Confidence Interval of the } \\
\text { Difference }\end{array}$ \\
\hline & & & & & Upper \\
\hline CAR & $-6,297$ & 44 & 000 &,- 0927756 &,- 122470 \\
\hline
\end{tabular}

\section{Sumber: Data Penelitian, 2020}

Berdasarkan hasil uji one sample t-test diatas dapat dilihat bahwa nilai signifikansi sebesar 0,000 $<0,05$. Nilai signifikansi $<0,05$ menunjukkan bahwa terdapat reaksi pasar pada 9 Maret.

Penelitian ini menggunakan metode event study yang diasumsikan bahwa pasar berbentuk setengah kuat, sehingga harga-harga saham yang terdaftar di bursa diharapkan mencerminkan secara penuh informasi yang dipublikasikan 
(Hartono, 2017). Informasi yang dipublikasikan tersebut dapat menjadi sinyal bagi para investor untuk mengambil keputusan dalam berinvestasi. Apabila informasi yang dipublikasikan mengandung sinyal negatif, maka akan timbul reaksi negatif dari investor yang ditandai dengan diperolehnya abnormal return negatif. Sementara itu, apabila informasi yang dipublikasikan mengandung sinyal positif, maka akan timbul reaksi positif dari investor yang ditandai dengan diperolehnya abnormal return positif di sekitar peristiwa tersebut.

Menurut Hartono (2017), menyatakan bahwa pasar saham memberikan reaksi positif terhadap suatu pengumuman maka pengumuman tersebut memiliki kandungan informasi. Pada 2 Maret 2020 saat Presiden RI mengumumkan kasus COVID-19 pertama di Indonesia, jumlah korban pada saat itu dilaporkan 2 orang. Sedangkan, pada 9 Maret 2020 jumlah korban 13 orang (Gugus Tugas Percepatan Penanganan COVID-19, 2020).

$\mathrm{H}_{1}$ : Terdapat reaksi pasar pada tanggal 2 Maret 2020.

Pada tanggal 2 Maret 2020 jumlah kasus positif adalah 2 orang. Hasil pengujian hipotesis telah menunjukkan bahwa pada tanggal 2 Maret 2020, ketika jumlah korban positif COVID-19 masih 2 orang pasar tidak bereaksi. Simpulan tersebut didapatkan dari nilai signifikansi sebesar 0,599 >0,05. Angka tersebut menunjukkan bahwa $\mathrm{H} 1$ ditolak dan $\mathrm{H} 0$ diterima.

Sumiari \& Putri (2020) dalam penelitiannya menyimpulkan bahwa, pengumuman kasus pertama COVID-19 ini cenderung berdampak negatif terhadap perusahaan di sektor perbankan dan properti. Hal ini dikarenakan COVID-19 akan mengganggu proses bisnis dan memberikan efek domino ke sektor perbankan, yaitu kemungkinan terjadinya kenaikan angka kredit macet karena pembatasan aktifitas. Begitu pula untuk sektor properti, COVID-19 dinilai akan melemahkan daya beli masyarakat atas aset properti karena berkurangnya pendapatan dan meningkatnya PHK.

Berdasarkan hasil penelitian Hindayani, (2020) sektor yang terkena dampak negatif dari adanya COVID-19 adalah sektor hotel, pariwisata, restoran dan transportasi. Sektor tersebut mendapatkan bad news akibat peristiwa ini dikarenakan akibat pemberlakuan PSBB. Sektor yang terkena dampak positif menurut Hindayani, (2020) adalah sektor farmasi, telekomunikasi serta makanan dan minuman. Sektor tersebut terkena dampak positif karena adanya investor yang cermat akan informasi bahwa sektor farmasi, telekomunikasi serta makanan dan minuman akan mendapatkan return diatas normal meski ditengah pandemi COVID-19, serta sektor tersebut relatif tidak terganggu adanya PSBB.

$\mathrm{H}_{2}$ : Terdapat reaksi pasar pada tanggal 9 Maret 2020.

Pada tanggal 9 Maret 2020 jumlah kasus positif bertambah menjadi 13 orang. Hasil pengujian secara statistik telah menunjukkan bahwa pada tanggal 9 Maret 2020, ketika jumlah korban positif COVID-19 bertambah menjadi 13 orang pasar bereaksi. Simpulan tersebut didapatkan dari nilai signifikansi sebesar 0,000 $<0,05$. Angka tersebut menunjukkan bahwa $\mathrm{H} 0$ ditolak dan $\mathrm{H} 2$ diterima. Hasil tersebut dapat terjadi karena Bursa Efek Indonesia dinyatakan efisien bentuk setengah kuat secara informasi (Dwipayana \& Wiksuana, 2017).

Efisiensi pasar bentuk setengah kuat hanya ditinjau dari informasi yang dipublikasikan ini disebut efisiensi pasar secara informasi (informationally efficient market). Pengujian untuk efisiensi pasar secara informasi ini tidak 
memperhatikan kecanggihan dari pelaku pasar di dalam menginterprestasikan dan menganalisis informasi lebih lanjut (Dwipayana \& Wiksuana, 2017).

Sambuari et al., (2020) dalam penelitiannya, menunjukkan bahwa terjadi kepanikan pasar terhadap aktivitas perdagangan setelah peristiwa pada 2 Maret 2020, sehingga adanya perbedaan frekuensi sebelum dan setelah peristiwa dari segi transaksi perdagangan. Rifa'i et al., (2020) dalam penelitiannya menyampaikan bahwa terdapat perbedaan IHSG antara sebelum dan setelah COVID-19. Dalam penelitian Subrata \& Werastuti, (2020) juga menyatakan bahwa terdapat perbedaan rata- rata yang signifikan abnormal return dan trading volume activity sebelum dan sesudah penetapan status darurat global ke level tertinggi terkait COVID-19 oleh WHO. Dalam penelitin Putri, (2020) menyatakan bahwa, harga saham pada saat sebelum pengumuman pertama kasus COVID-19, pada saat pengumuman pertama kasus COVID-19, dan pada saat 3 bulan setelah pengumuman pertama kasus COVID-19 menunjukkan bahwa terdapat perbedaan yang signifikan antara harga saham di ketiga periode tersebut. Pandemi COVID-19 juga mengakibatkan depresiasi rupiah terhadap dolar AS pada 23 Maret 2020 (Putri \& Amanah, 2020).

\section{SIMPULAN}

Berdsarkan hasil pengujian hipotesis, dapat disimpulkan bahwa tidak terdapat reaksi pasar pada 2 Maret 2020. Hal ini menunjukkan bahwa ketika pada 2 Maret 2020 jumlah korban terkonfirmasi positif COVID-19 masih sedikit, pasar tidak bereaksi.

Berdsarkan hasil pengujian hipotesis, dapat disimpulkan bahwa terdapat reaksi pasar pada tanggal 9 Maret 2020. Hal ini menunjukkan bahwa ketika pada 9 Maret 2020 jumlah korban terkonfirmasi positif COVID-19 meningkat, pasar bereaksi. Reaksi pasar tersebut terjadi karena adanya peningkatan jumlah korban terkonfirmasi positif COVID-19 dibanding pada 2 Maret 2020.

Berdasarkan hasil dan pembahasan serta simpulan pada penelitian ini, adapun saran-saran yang dapat diberikan dalam penelitian ini, yaitu: Bagi investor (a) Perlu adanya pemahaman secara keseluruhan terkait dengan pasar modal guna membantu dalam mengenali risiko yang terjadi pada saat melakukan investasi, sehingga dapat membantu investor dalam melakukan aktivitas di pasar modal. (b) Sebagai salah satu upaya meminimalkan resiko apabila terjadi peristiwa tak terduga yang menyebabkan pasar volatile, investor perlu berhati-hati dan meningkatkan pemahaman terhadap informasi yang menjadi penyebab pasar menjadi volatile. Bagi penelitian selanjutnya (a) Penentuan event date sebagai titik t0 harus dipertegas apakah tanggal yang ditetapkan benar-benar waktu klimaks dalam peristiwa yang diamati. Hal ini agar tidak menimbulkan penelitian yang "salah sasaran" karena kesalahan penentuan event date. (b) Penelitian selanjutnya diharapkan untuk mencoba dengan menggunakan model perhitungan yang lain seperti mean adjusted model atau market model, sehingga konsistensi dari hasil penelitian ini dapat dilihat. (c) Penelitian selanjutnya diharapkan dapat menambahkan trading volume activity (TVA) atau aktivitas volume perdagangan sebagai salah satu indicator dalam penelitian. 


\section{REFERENSI}

ANTARA.news. (2020). Presiden umumkan kasus infeksi corona pertama di Indonesia. Antaranews.Com. https://www.antaranews.com/berita/1329594/presiden-umumkan-kasusinfeksi-corona-pertama-di-indonesia

Aryasa, I. P. G. C. A., \& Suaryana, I. G. N. A. (2017). Reaksi Pasar Sebelum Dan Sesudah Pengumuman Right Issue. E-Jurnal Akuntansi Universitas Udayana, 18.2, 1426-1454.

Beaver, W. H. (1989). Financial Reporting: An Accounting Revolution (2nd ed). Prentice-Hall.

Bodie, Z., Kane, A., \& Marcus, A. J. (2008). Investments (7th ed.). McGraw-Hill.

Brown, S. J., \& Warner, J. B. (1985). Using daily stock returns. The case of event studies. Journal of Financial Economics, 14(1), 3-31. https://doi.org/10.1016/0304-405X(85)90042-X

CNBC Indonesia. (2020a). "Doping" BI-The Fed Buat IHSG Melesat 5\% Lebih, Dalam 2 Hari - Halaman 2. Cnbcindonesia.Com. https://www.cnbcindonesia.com/market/20200304162245-17142510/doping-bi-the-fed-buat-ihsg-melesat-5-lebih-dalam-2-hari/2

CNBC Indonesia. (2020b). Virus Corona Bikin Bursa Saham Dunia Rontok. Cnbcindonesia.Com.https://www.cnbcindonesia.com/market/202001281115 58-17-133295/virus-corona-bikin-bursa-saham-dunia-rontok/1

databoks.katadata.co.id. (2020). The Fed Pangkas Suku Bunga 50 Bps Akibat Corona, Tertinggi Sejak 2008 Databoks. Databoks.Katadata.Co.Id. https://databoks.katadata.co.id/datapublish/2020/03/04/the-fedpangkas-suku-bunga-acuan-50-bps-akibat-corona-tertinggi-sejak-2008

Detiknews. (2020). Corona Ditetapkan Jadi Bencana Nasional, Pemerintah Semua Transparan. News.Detik.Com. https://news.detik.com/berita/d4976750/corona-ditetapkan-jadi-bencana-nasional-pemerintah-semuatransparan

Fama, E. (1970). Efficient Capital Markets: A Review of the Theory. The Journal of Finance, 25(2), 383-417.

Foster, G. (1986). Financial Statement Analysis (2nd ed.). Prentice Hall.

Ghozali, H. I. (2016). Aplikasi Analisis Multivariete dengan Program IBM SPSS 23 (8th ed.). Badan Penerbit Universitas Diponegoro.

Halodoc.com. (2020). WHO Tetap Virus Corona Masuk Global Health Emergency, Ini 7 Faktanya. Halodoc.Com. https://www.halodoc.com/whotetapkan-virus-corona-masuk-global-health-emergency-ini-7-faktanya

Hanafi, M. M. (2004). Manajemen Keuangan (Kesatu). BPFE Universitas Gadjah Mada.

Hartono, J. (2017). Teori Portofolio dan Analisis Infestasi (11th ed.). BPFE Universitas Gadjah Mada.

Hatmanti, A., \& Sudibyo, B. (2017). Pengaruh Pelantikan Kabinet Kerja Hasil Reshuffle Jilid Ii Terhadap Harga Saham LQ-45. Jurnal Economia, 13(1), 1. https://doi.org/10.21831/economia.v13i1.11797

Indrayuda, A. A. G. A., \& Sukartha, I. M. (2019). Reaksi Pasar Modal Atas Kenaikan The Federal Funds Rate Pada Tanggal 26 September 2018. E-Jurnal $\begin{array}{llll}\text { Akuntansi Universitas Udayana, 29(2), } & 854 .\end{array}$ 
https:// doi.org/10.24843/ eja.2019.v29.i02.p27

Investor Daily. (2020). Sejak Korona Pertama Kali Dilaporkan, IHSG Sudah Turun 6,59\%. Investor.Id. https://investor.id/market-and-corporate/sejakkorona-pertama-kali-dilaporkan-ihsg-sudah-turun-659

Jati, I. K., \& Sanjiwani, P. D. A. (2017). Reaksi Pasar Modal Terhadap Kebijakan Tax Amnesty Pada Saat Pengumuman Dan Akhir Periode I. E-Jurnal Akuntansi Universitas Udayana, 19.1, 799-826.

Katadata.co.id. (2020a). Jokowi Umumkan Dua WNI Positif Virus Corona, IHSG Sesi I Turun 1,02\%. Katadata.Co.Id. https://katadata.co.id/berita/2020/03/02/jokowi-umumkan-dua-wnipositif-virus-corona-ihsg-sesi-i-turun-102

Katadata.co.id. (2020b). Selain Virus Corona, 4 Penyakit Ini Pernah Ditetapkan Darurat oleh WHO.

Katadata.Co.Id. https://katadata.co.id/berita/2020/01/31/selain-virus-corona-4-penyakitini-pernah-ditetapkan-darurat-oleh-who

Kontan.co.id. (2020a). Bursa Asia merah, indeks Shanghai anjlok lebih dari 8\%. Investasi.Kontan.Co.Id. https://investasi.kontan.co.id/news/bursa-asiamerah-indeks-shanghai-anjlok-lebih-dari-8

Kontan.co.id. (2020b). Dampak pemangkasan suku bunga The Fed terhadap penguatan IHSG diprediksi sementara - Page all. Investasi.Kontan.Co.Id. https://investasi.kontan.co.id/news/dampak-pemangkasan-suku-bungathe-fed-terhadap-penguatan-ihsg-diprediksi-sementara?page=all

Kothari, S. P., \& Warner, J. B. (2007). Econometrics of Event Studies. In B. E. Eckbo (Ed.), Handbook of Empirical Corporate Finance SET (Vol. 1, Issue 06). Woodhead Publishing Limited. https://doi.org/10.1016/B978-0-444-532657.50015-9

Maharani, A. A. I. A. (2014). Respon Pasar Atas Informasi Laba. E-Jurnal Akuntansi Univeristas Udayana, 8(1), 83-93.

Mahendra, I. K. R., \& Rasmini, N. K. (2019). Reaksi Pasar Terhadap Kenaikan Bank Indonesia 7-Day Reverse Repo Rate Tanggal 15 Agustus 2018. E-Jurnal Akuntansi Universitas Udayana, 27, 2066. https://doi.org/10.24843/eja.2019.v27.i03.p16

McWilliams, T. P. M. \& V. B. (2011). Another Look At Theoretical And Em-pirical Issues In Event Study Methodology. Journal of Applied Business Research, 16(3).

Melati, D. A., Saryadi, \& Widiartanto. (2015). Analisis Reaksi Pasar Modal atas Peristiwa Pemilihan Presiden 9 Juli 2014 (Event Study pada Indeks Saham LQ-45). Jurnal Ilmu Administrasi Bisnis, 4(2), 284-294.

Nguyen, H. N. A. P. V. R. I. M. J. H. N. (2017). The Effects of Regulatory Announcements on Risk and Return: The Vietnamese. Pacific Accounting Review, 29(2). https://doi.org/http://dx.doi.org/10.1108/PAR-08-20160077

Octavera, S., \& Rahadi, F. (2019). Reaksi Pasar Modal terhadap Peristiwa Ekstrim dan Radikalisme (Studi Pasca Serangan Teroris di Surabaya). Manajemen Dan Kewirausahaan, 10(1), 59. https://doi.org/10.31317/jmk.10.1.59-69.2019

P, H. M., \& Yasa, G. W. (2015). Perbedaan Reaksi Pasar Atas Pengumuman Pemecahan Saham Pada Lq45 Dan Non Lq45. Jurnal Ilmiah Akuntansi Dan 
Bisnis Universitas Udayana, 10(2), 96-104.

Pertiwi, N. P. A., \& Wirama, D. G. (2019). Reaksi Pasar atas Deviden Initiation dan Deviden Omission. E-Jurnal Akuntansi Universitas Udayana, 26(2), 11901214.

Peterson, P. P. (1989). Event Studies: A Review of Issues and Methodology. Quarterly Journal of Business and Economics, 28(3), 36-66. http://www.jstor.org/stable/40472954

Keputusan Presiden Republik Indonesia Nomor 12 Tahun 2020, Kementrian Sekretariat Negara (2020).

Putra, I. M. D. H., \& Putri, I. G. A. M. A. D. (2018). Analisis Reaksi Pasar Sebelum dan Sesudah Pengumuman Kemenangan Donald Trump Menjadi Presiden Amerika Serikat. E-Jurnal Akuntansi Universitas Udayana, 23, 406. https://doi.org/10.24843/eja.2018.v23.i01.p16

Repousis, S. (2016). Abnormal stock returns in Greece during the Cypriot banking crisis. Journal of Money Laundering Control, 19(2), 122-129.

Rofiah, S., Maslichah, \& Mawardi, M. C. (2019). REAKSI INVESTOR TERHADAP ISU PENCABUTAN DMO DAN MELEMAHNYA KURS RUPIAH. E-JRA Universitas Islam Malang, 08(01), 1-13.

Sopyana, N. P. L., \& Yasa, G. W. (2016). Pemilihan Presiden Dan Wakil Presiden Republik Indonesia Tahun 2014. 21(2), 136-146.

Sugiyono. (2017). Metode Penelitian Bisnis. Alfabeta.

Syahyunan. (2015). Manajemen Keuangan (Perencanaan, Analisis dan Pengendalian Keuangan) (Ketiga). USU Press.

Tandelilin, E. (2010). Portofolio dan Infestasi (Edisi Pertama). Kanisius.

Wahyudhi, P. S., \& Suaryana, I. G. N. A. (2019). Reaksi Pasar Atas Kesepakatan Investasi Bidang Infrastruktur dalam Pertemuan International Monetary Fund-World Bank 2018. E-Jurnal Akuntansi Univeristas Udayana, 27, 594-643. https://doi.org/10.24843/eja.2019.v27.i01.p23

Warta Ekonomi.co.id. (2020). WHO Tetapkan COVID-19 Jadi Nama Resmi Virus Corona. Wartaekonomi.Co.Id. https://www.wartaekonomi.co.id/read271393/who-tetapkan-covid-19jadi-nama-resmi-virus-corona-ini-artinya

Watts, R. L., \& Zimmerman, J. L. (1990). Positive Accounting Theory: A Ten Year Perspective. The Accounting Review, 65(1), 131-156.

Wikipedia.org. (2020). Wabah penyakit koronavirus 2019-2020 - Wikipedia bahasa Indonesia.

https://id.wikipedia.org/wiki/Wabah_penyakit_koronavirus_2019-2020 